\title{
Unusual kinetics of strain-induced diffusional phase transformations in $\mathrm{Cu}-\mathrm{Cr}-\mathrm{Zr}$ alloy
}

\author{
S. N. Faizova ${ }^{1}$, D. A. Aksenov ${ }^{\dagger, 2,3}$, I. A. Faizov ${ }^{4}$, K. S. Nazarov ${ }^{4}$ \\ †AksyonovDA@mail.ru
}

\author{
${ }^{1}$ Bashkir State University, Sterlitamak Branch, Sterlitamak, 453103, Russia \\ ${ }^{2}$ Institute of Molecule and Crystal Physics UFRC RAS, Ufa, 450075, Russia \\ ${ }^{3}$ Ufa State Aviation Technical University, Ufa, 450008, Russia \\ ${ }^{4}$ Institute for metals superplasticity problems RAS, Ufa, 450001, Russia
}

\begin{abstract}
This paper reports experimental results demonstrating nonmonotonic changes of the solid solution concentration in the process of high-pressure torsion of the preliminary aged $\mathrm{Cu}-\mathrm{Cr}-\mathrm{Zr}$ alloy. The solid solution concentration which is very low in the initial state passes through a maximum before it finally stabilizes at a lower value. Such a behavior is, strictly speaking, impossible for a purely diffusion-controlled process under stationary conditions. Observations on the evolution of the second phases particles in the course of deformation suggest a possible mechanism behind this phenomenon. Severe deformation causes refinement of the particles initially present in the alloy by, most probably, quasi-brittle fracture, what creates fragments with sharp edges and makes possible their partial dissolution by Gibbs-Thomson mechanism. The morphology and sizes of the partially dissolved fragments as well as of newly precipitated particles make them less susceptible to fracture than those formed by the preliminary aging. So, under severe deformation, unlike the usually considered models, a "dissolving" subset of particles evolves not only due to diffusion; in the other words, the deformation creates a difference between "dissolving" and "precipitating" subsets of particles. As combined fracture and dissolution transform the initial ensemble of particles, the dissolution gradually slows down unlike the precipitation, which rate is controlled by the solution concentration and density of precipitation sites. As a result, these processes first reach a transitional balance, corresponding to the maximum concentration, and later a stable dynamic equilibrium on its lower level.
\end{abstract}

Keywords: severe plastic deformation, phase transformation, diffusion, copper alloys.

УДК: 538.9

\section{Необычная кинетика деформационно-индуцированных фазовых превращений в сплаве $\mathrm{Cu}-\mathrm{Cr}-\mathrm{Zr}$}

\author{
Фаизова С. Н. ${ }^{1}$, Аксенов Д. А. ${ }^{\dagger, 2,3}$, Фаизов И. А. ${ }^{4}$, Назаров К. С. ${ }^{4}$ \\ ${ }^{1}$ Башкирский государственный университет, Стерлитамакский филиал, Стерлитамак, 453103, Россия \\ ${ }^{2}$ Институт физики молекул и кристаллов УФИЦ РАН, Уфа, 450075, Россия \\ 3уУимский авиационный технический университет, Уфа, 450008, Россия \\ ${ }^{4}$ Институт проблем сверхпластичности металлов РАН, Уфа, 450001, Россия
}

В данной работе представлены экспериментальные результаты, демонстрирующие немонотонное изменение концентрации твердого раствора в процессе кручения под высоким давлением предварительно состаренного сплава $\mathrm{Cu}-\mathrm{Cr}-\mathrm{Zr}$. Исходно низкая концентрация твердого раствора, увеличиваясь в процессе интенсивной деформации, проходит через максимум, прежде чем стабилизируется при более низком значении. Такое поведение, строго говоря, невозможно для процесса, контролируемого диффузией, в стационарных условиях. Наблюдения за эволюцией частиц вторых фаз в процессе деформации позволяют предположить возможный механизм этого явления. Интенсивная деформация вызывает измельчение частиц, изначально присутствующих в сплаве, за счет, вероятнее всего, квазихрупкого разрушения, что создает фрагменты с острыми ребрами и делает возможным их частичное растворение по механизму Гиббса-Томсона. Морфология и размеры частично растворенных фрагментов и вновь выделившихся частиц делают их менее подверженными разрушению, чем те, которые образовались в результате предварительного старения. Таким образом, при интенсивной деформации, в отличие от обычно рассматриваемых моделей, «растворяющееся» подмножество частиц эволюционирует не только за счет диффузии. Другими словами, деформация создает разницу между «растворяющимся» и «выпадающим» подмножествами частиц. По мере того, 
как сочетание разрушения и растворения трансформирует исходный ансамбль частиц, растворение постепенно замедляется в отличие от выделения, скорость которого контролируется концентрацией раствора и плотностью сверхкритических зародышей. В результате эти процессы сначала достигают переходного баланса, соответствующего максимальной концентрации, и только затем стабильного динамического равновесия при более низком ее значении.

Ключевые слова: интенсивная пластическая деформация, фазовые превращения, диффузия, медные сплавы.

\section{Introduction}

Properties of dispersion strengthened alloys strongly depend on distribution of secondary phase particles. This fact acquires an additional significance due to the expanding application of severe plastic deformation (SPD) for formation of nano/ultrafine-grained structure [1,2]. The dynamic strain ageing and the deformation-induced dissolution of second phases reach considerable level under the conditions of SPD processing [3], thus significantly influencing the functional properties of the produced material. For the $\mathrm{Cu}-\mathrm{Cr}$ system, particularly for the important case of $\mathrm{Cu}-\mathrm{Cr}-\mathrm{Zr}$ alloys, the deformation induced dissolution with the formation of the supersaturated solid solution was reported in a number of articles $[4,5]$. Nonetheless, the mechanism and the kinetics of dissolution remain virtually uninvestigated.

A displacement of the phase coexistence line relative to its position in the equilibrium phase diagram may be due to the contributions to Gibbs free energy from the adsorption of alloying atoms to dislocations and other structural defects introduced by SPD. The significance of this effect depends on the particular alloy composition and, apparently, in many cases is not sufficient to explain observed phenomena. For example, though for a well-studied case of pearlitic steel [6-10], it is known that the binding enthalpy of carbon interstitials to dislocation in ferrite is larger than their dissolution heat in cementite [9], the transfer of carbon atoms to dislocations alone seems insufficient to explain the formation of supersaturated solution $[6,8]$. On the other side, the concentration of solid solution in the vicinity of particles is higher than in the bulk of material because of Gibbs-Thompson effect. The excess depends on the curvature of the particle surface and the energy of the particlematrix interface. SPD influences both these values: in course of deformation particles decrease in size - mechanisms behind this may be different: from the brittle or quasi-brittle fracture to dislocation shearing and co-deformation with the matrix and their interfaces react with dislocations, thus increasing the surface energy. Combined, these two factors may lead to dissolution of a considerable fraction of the second phase and to the formation of supersaturated solution.

The lattice diffusion coefficient for $\mathrm{Cr}$ in copper [11] at temperatures not much higher than the room temperature is too small to explain the observed phenomena, so high density of defects created by SPD plays an essential role, enhancing also such mechanisms as the grain boundary and dislocation core diffusion. Acceleration of the diffusional transfer becomes most significant after the accumulated strain reaches some critical value what is related to activation of noncrystallographic modes of deformation and the corresponding intensification of point defects production [12].

It should be noted that the increase of the diffusion coefficient does not change by itself the qualitative picture of the second phase dissolution and precipitation because in the diffusion equation this parameter only sets a temporal scale of processes. SPD, as it was discussed above, may act also as a driving force of particles dissolution, or, from the formal view-point, change boundary conditions of the diffusion equation and, generally, makes that in a non-stationary way. This fact may result in such a behavior of the solutes concentration that is qualitatively different from what might be expected in a "classical" diffusion-controlled process.

In the previous work [4] of the authors the formation of supersaturated solid solution in $\mathrm{Cu}-\mathrm{Cr}-\mathrm{Zr}$ alloy subjected to equal channel angular pressing was demonstrated and a tentative mechanism of this process was discussed. The aim of present article is to extend the research to higher strain values and quantitively study a kinetics of the deformationinduced second phases dissolution to reveal those its features that may provide the deeper understanding of interactions between SPD and phase transitions.

\section{Experimental procedure}

The industrial alloy with the nominal composition $\mathrm{Cu}-0.6 \% \mathrm{Cr}-0.1 \% \mathrm{Zr}$ (wt.\%) had, in the as-delivered state, Vickers hardness $1500 \mathrm{MPa}$ and conductivity $83 \%$ IACS. Rods of the alloy were further aged at $450^{\circ} \mathrm{C}$ to reduce the residual solid solution concentration of the alloying elements. Stable values of the microhardness and conductivity were achieved after 4 hours of annealing. In this state the lattice parameter of the alloy is close to that of pure copper.

Vickers hardness was tested on Micromet 5101 microhardness tester with $0.1 \mathrm{~kg}$ load and $10 \mathrm{~s}$ loading time, electrical conductivity was measured with a VE-27VNC eddy current conductivity meter having an accuracy $0.5 \mathrm{MS} / \mathrm{m}$. The X-ray analyses were carried out with a Bruker D8 ADVANCE type diffractometer using the $\mathrm{Cu}-\mathrm{K}_{\alpha 1}$ line.

Samples with a diameter of $10 \mathrm{~mm}$ and a thickness of $2 \mathrm{~mm}$ were deformed by high-pressure torsion (HPT) at room temperature using a pressure of $6 \mathrm{GPa}$ with a rate $1 \mathrm{~min}^{-1}$ up to 10 turns with a step of 1 turn. Five samples were used for each of the examined strain values.

Properties and the structure of the deformed samples were studied in a region with the diameter of $3 \mathrm{~mm}$ located at the middle of the disk radius. The structure was examined with a Tescan Mira 3LMH scanning electron microscope and with a Jeol-2100 transmitting electron microscope using thin foils and carbon extraction replicas. Calculations of the particle distribution density were made on areas $\geq 15 \mu \mathrm{m}^{2}$ with 200 to 10000 particles in a sample.

\section{Results and discussion}

The most detailed data on the strain-induced dissolution of second phase particles are available for iron-based alloys where Curie temperature, the coercive force and some 
other properties sensitive to dissolved elements may be used for measurement of the solid solution concentration. For low-alloyed bronzes an analogous role is played the electrical conductivity, which at room temperature only weakly depends on the density of structural defects and serves, along with the X-ray analysis, as a sensitive measure of changes in the solid solution concentration [13]. The conductivity of alloy samples as a function of the number of HPT turns is shown in Fig. 1. This graph demonstrates a distinct minimum in the vicinity of 6 turns.

According to the large amount of data analyzed and compiled in [14], at room temperature an increase in electrical resistivity of pure copper with cold work saturates at a value about $0.4 \mathrm{n} \Omega \mathrm{m}$ after strain of 0.77 . The decrease in conductivity corresponding to this value at an initial conductivity of $100 \%$ IACS is $2.4 \%$, and in a range of the conductivity values observed in the present experiment it does not exceed the measurement error. Thus, the changes of the conductivity in the course of the strain accumulation should be attributed to dissolved impurities. Contributions to electrical resistivity of pure copper from different impurity elements for low concentrations are proportional to their contents and are listed in Table 1.

The conductivity of alloy samples even after a prolonged annealing, i.e., when chromium and zirconium are practically absent in the solid solution, is markedly lower than that of copper, what is caused, mainly, by the presence of such contaminations as iron and oxygen, which exert strong influence on conductivity and are difficult to remove from industrial copper alloys. Though, these contributions, unlike those due to the alloying elements, do not vary significantly in the course of the employed SPD treatment and may be considered constant.

An additional data that is required to determine the individual concentrations of both alloying elements may be provided by the X-ray analysis. As the conductivity has set an overall picture of changes in the solid solution concentration, the lattice parameter was measured only for key values of deformation (Fig. 2). As it may be seen from the presented data, the lattice parameter of the alloy also changes nonmonotonically with the increase of the strain and has a maximum at 6 turns.

In the solid spheres model, the atomic radius of pure chromium is equal to $0.12490 \mathrm{~nm}$ and smaller than the corresponding value for copper, $0.12782 \mathrm{~nm}$. Basing on this fact, a suggestion is often made [16,17] that the solid solution of chromium in copper should have a smaller lattice parameter than pure copper. This conclusion seems to be oversimplified because, while taking into account the difference in the atomic radii, it totally ignores a significant dissimilarity of outer electronic shells of these elements, which manifests itself when a chromium atom is surrounded by copper ones.

Table 1. Increase in resistivity of copper with impurity elements in solid solution.

\begin{tabular}{|c|c|}
\hline Impurity element & Increase in resistivity, $\mathrm{n} \Omega \cdot \mathrm{m} / \mathrm{at} . \%$ \\
\hline $\mathrm{O}$ & $530[14]$ \\
\hline $\mathrm{Fe}$ & $99[14]$ \\
\hline $\mathrm{Cr}$ & $39[14]$ \\
\hline $\mathrm{Zr}$ & $34[15]$ \\
\hline
\end{tabular}

Measurements [13,18-20] made on supersaturated solid solutions produced by the ultrafast cooling demonstrate a linear increase of the lattice parameter, a, with the concentration of a dissolved element. The measured coefficients for the copper matrix are $\delta a /[\mathrm{Cr}]=0.26 \div 0.31 \cdot 10^{-3} \mathrm{~nm} / \mathrm{at} . \%[13,18,19]$ and $\delta a /[\mathrm{Zr}] \approx 0.16 \cdot 10^{-2} \mathrm{~nm} /$ at.\% [20], where $[\mathrm{Cr}]$ and $[\mathrm{Zr}]$ stand for the concentrations of corresponding elements.

As the content of the alloying elements in alloy under study is rather low, their contributions to the increase of the lattice parameter as well as to the resistivity may be considered as additive. Based on this assumption, concentrations of chromium and zirconium in solid solution were calculated from the above data (Fig. 3).

Taking into account that the accuracy of the empirical coefficients used in this calculation is estimated to be $15 . . .20 \%$, the presented values show satisfactory agreement with the alloy composition. They agree also with those properties of the material which depend on the solid solution concentration less directly - Vickers microhardness (Fig. 4) and the distribution density of the second phase particles as a function of their size (Fig. 5).

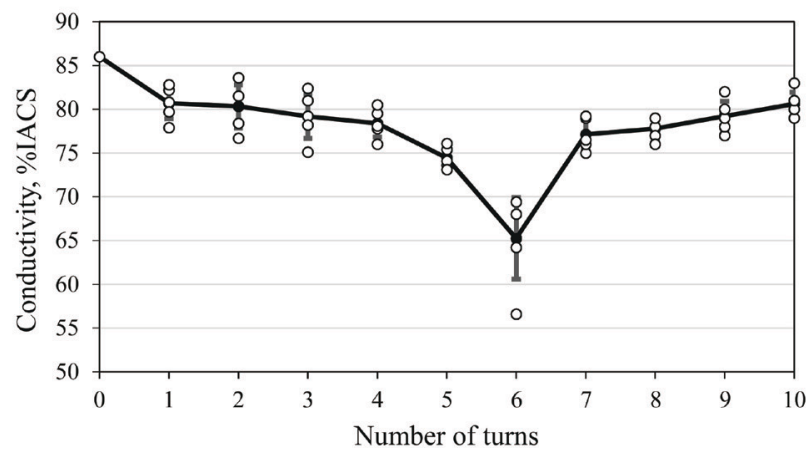

Fig. 1. Electroconductivity of samples as a function of the number of HPT turns.

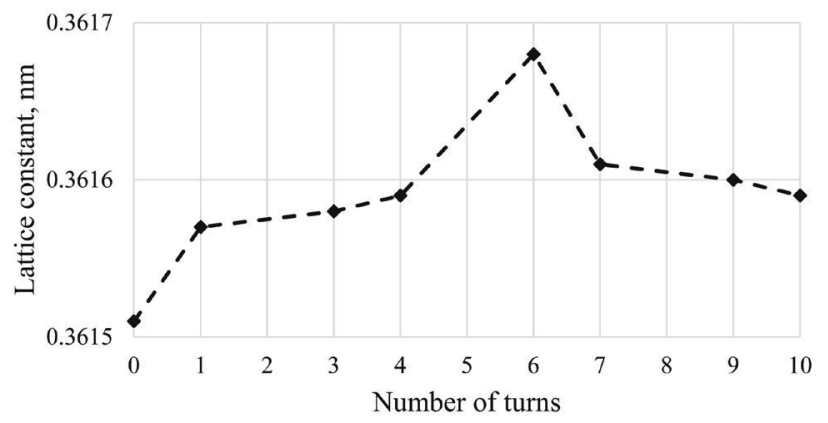

Fig. 2. Lattice parameter of samples as a function of a number of turns.

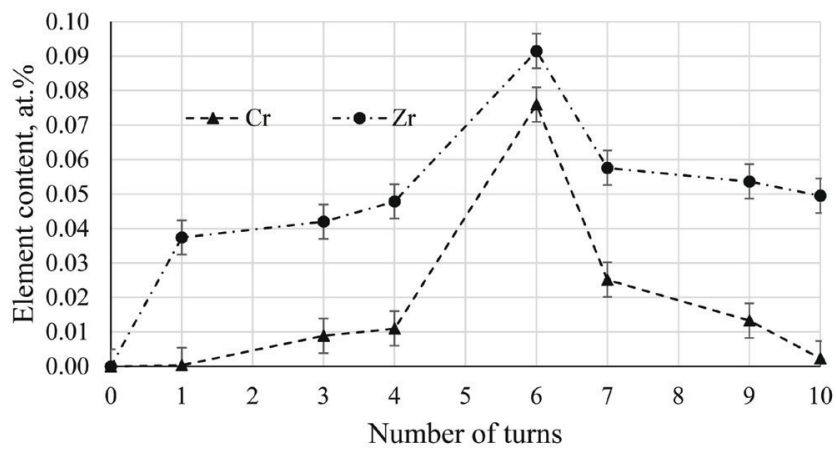

Fig. 3. Calculated content of alloying elements in solid solution. 


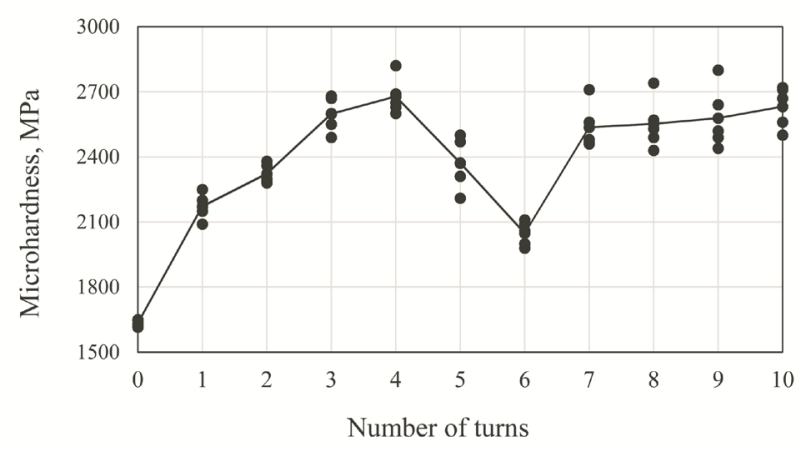

Fig. 4. Vickers microhardness of samples vs number of turns.

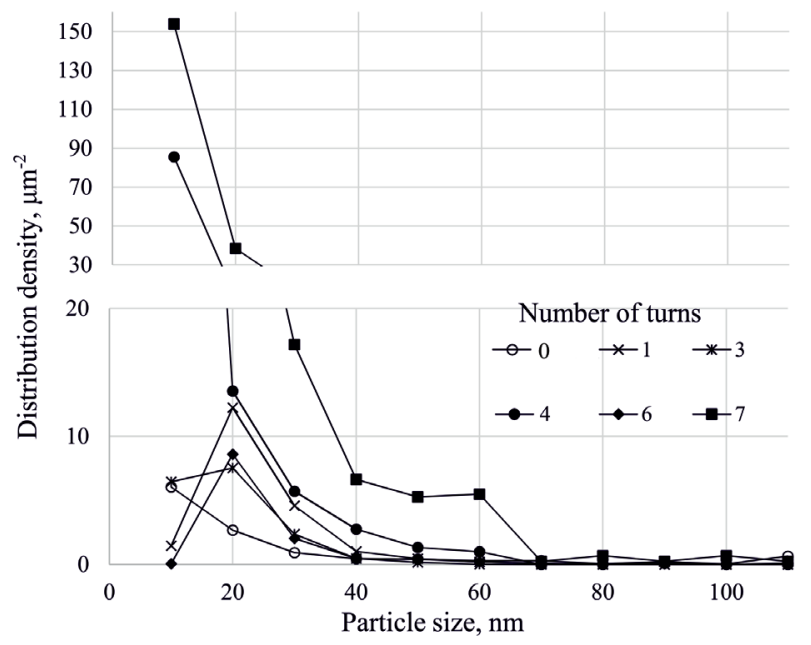

Fig. 5. Particle distribution density as function of their size and number of HPT turns.

In the initial state the material is overaged, has a coarsegrained structure and contains no solid solution; as a consequence, its microhardness is rather low. Its increase after the first turns of HPT is caused, evidently, by the dislocation and structural hardening. The further increase to the highest value, $2650 \mathrm{MPa}$, at 4 turns is clearly connected to the dispersion strengthening - the density of small particles markedly increases at this stage of deformation. A probable cause for this increase is fracturing of the initially present particles. In the course of the next two turns the particles density again drops. At this stage of deformation an increase in the solid solution concentration is observed, so this drop is evidently caused by the dissolution of a considerable fraction of particles as it may be seen in Fig. 5. Solid solution strengthening is not very significant for the alloy under consideration, so its contribution may not compensate for the corresponding loss of precipitation strengthening. With further deformation the observed decomposition of the solid solution gives rise to high density of small particles what leads again to an increase in the microhardness.

The observed changes of the solid solution concentration may seem contradictory to some general principles of diffusion-controlled phase transitions: under stationary conditions (the deformation in in the present work proceeds at the constant rate and the constant pressure, temperature variations are negligible) it should be expected that the minimum and the maximum of the concentration take place in the initial and final states. However, in the present case the evolution of one of the phases, the particles, is governed not only by diffusion but also directly influenced by the plastic flow of the material. A refinement of the second phase particles is commonly observed in the process of SPD [4]. For the material under investigation, it takes place, most probably, via quasi-brittle fracture in the stress fields of dislocation pile-ups. The form of particles plays a significant role in this process - elongated or irregular-shaped particles are subjected to greater stress concentration and easier to break than rounded ones. For small particles this process is also less effective because they are easily bypassed by dislocations and corresponding pile-ups generally have smaller sizes. Fragments of fractured particles have sharp ribs and may partially dissolve via Gibbs-Thomson mechanism.

The fracture of the particles is preceded and partially overlaps with their structural evolution [12]: penetration of shear bands and uncompleted shear from the matrix that leads to formation of steps on the interface serving stress concentrators. An effective, i.e., calculated from such bulk properties as the electrical resistance and the lattice parameter, concentration of solid solution depends as on the portion of dissolved particles as well as on the diffusion coefficient, which dramatically increases with development of noncrystallographic modes of deformation and corresponding rise of the density of defects. As a result, the content of dissolved elements rises sharply after a certain deformation, for chromium this deformation is achieved approximately at fourth turn. Zirconium is present in the alloy in the form of intermetallics [21] that fracture easier than chromium particles what explains the earlier rise of its concentration and its fuller dissolution.

A resource of the deformation-induced dissolution by the above mechanism is limited by an amount of particles that have suitable form and size in the ensemble formed during the preliminary aging, so the dissolution process gradually slows down and at some moment reaches an equilibrium with a concurrent process of the precipitation from solid solution. This equilibrium is only transient as the former process further slows down with the dwindling of easy fracturable particles and, thus, their dissolvable fragments, while the latter, which is controlled by the solution concentration and the density of precipitation sites, would for some time retain a higher rate.

As deformation proceeds further, the initial ensemble of particles is replaced by the partially dissolved particle fragments and small particles newly created by the decay of supersaturated solution. The changes of a typical form and the distribution density of particles are illustrated in Fig. 6 a,b; in Fig. $6 \mathrm{c}$ an example of a fractured particle is also shown. The form and sizes of particles in the new ensemble make them less prone to the fracture, so the final concentration of solid solution, corresponding to a seemingly stable equilibrium between dissolution and precipitation, is established at a lower level than its maximal value.

In the framework of the proposed model of deformationinduced dissolution, the kinetics of the process, especially such its feature as non-monotonic changes of the solid solution concentration, sensitively depends of on properties of the initial state. That probably explains the absence of 


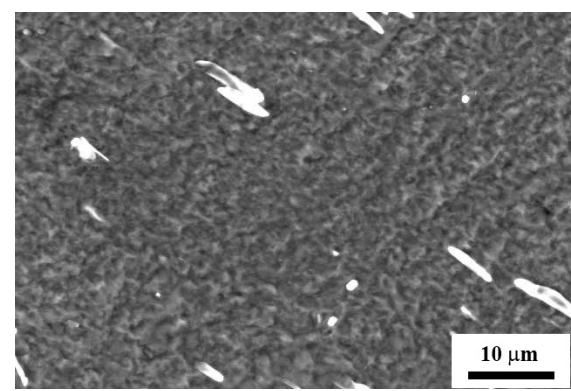

a

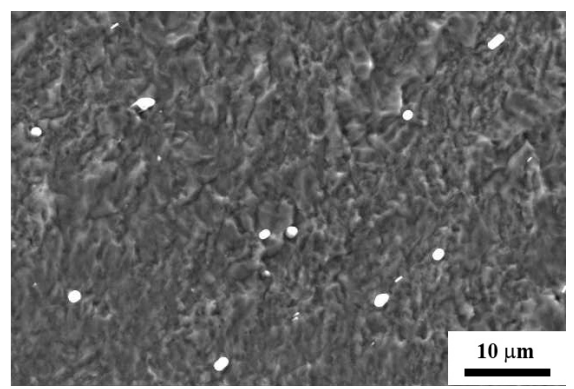

b

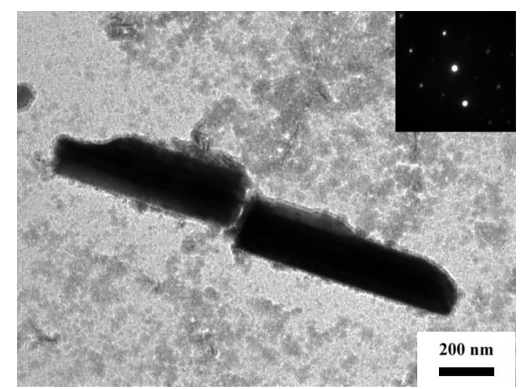

c

Fig. 6. SEM images of particles in the alloy after the first (a) and the sixth (b) turns. A fractured particle, TEM replica (c).

observations of this effect in similar experiments [22,23], though a non-monotonic change of $\mathrm{Zr}$ content in solid solution during was also reported [24] the mechanical alloying process.

\section{Summary and conclusions}

In the process of deformation of preliminary aged $\mathrm{Cu}-\mathrm{Cr}-\mathrm{Zr}$ alloy by HPT, non-monotonic changes of physical and mechanical properties as well as the particle distribution density were observed. That behavior is closely related to changes in the concentration of dissolved alloying elements. An unusual, for diffusion-controlled phase transitions, kinetics of the dissolution-precipitation may be explained taking into account an active role that SPD plays in this process.

During the first several turns of HPT the solid solution concentration increases due to the dissolution of the second phases. A relatively high rate of the process on this stage of deformation depends on specific morphological features of the second phase particles formed during the preliminary treatment, namely, on their propensity to fracture with subsequent partial dissolution of fragments via GibbsThomson mechanism. As the plastic strain accumulates, the initial ensemble of particles is gradually replaced by partially dissolved fragments of the primary particles and by newly formed small particles less prone to fracture. This evolution provides an additional factor for slowing down the dissolution process besides the increase of the solution concentration and changes in the particle size distribution. As a result, the solid solution concentration begins to decrease until it reaches an approximately stable value, corresponding, presumably to a dynamical equilibrium between the deformation-driven dissolution and the precipitation from supersaturated solid solution.

Thus, it may be stated that the active role of SPD in this experiment consists in that it provides mechanisms to change properties of one of phases involved in the transformation, the particles, independent of the diffusion.

\section{References}

1. C.C. Koch, T.G. Langdon, E. J. Lavernia. Metall. Mater. Trans. A. 48, 5181 (2017). Crossref

2. N. Tsuji, T. Maki. Scr. Mater. 60, 1044 (2009). Crossref

3. A. Mazilkin, B. Straumal, A. Kilmametov, P. Straumal, B. Baretzky. Mat. Trans. 60, 1489 (2019). Crossref
4. I. A. Faizov, R. R. Mulyukov, D. A. Aksenov, S. N. Faizova, N. V. Zemlyakova, K. R. Cardoso, Yu. Zeng. Lett. Mater. 8 (1), 110 (2018). (in Russian) [И. А. Фаизов, Р. Р. Мулюков, Д.А. Аксенов, С.Н. Фаизова, Н.В. Землякова, K. Cardoso, Y. Zeng. Письма о материалах. 8 (1), 110 (2018).] Crossref

5. A. Bachmaier, G.B. Rathmayr, M. Bartosik, D. Apel, Z. Zhang, R. Pippan. Acta Mater. 69, 301 (2014). Crossref

6. X. Sauvage, J. Copreaux, F. Danoix, D. Blavette. Phil. Mag. A. 80, 781 (2000). Crossref

7. V.G. Gavriljuk. Mater. Sci. Eng. A. 345, 81 (2003). Crossref

8. Yu. Ivanisenko, W. Lojkowski, R.Z. Valiev, H.-J. Fechta. Acta Mater. 51, 5555 (2003). Crossref

9. N. Guelton, M. François. Metall Mater. Trans. A. 51, 1602 (2020). Crossref

10. J. Languillaume, G. Kapelski, B. Baudelet. Acta Mater. 45, 1201 (1997). Crossref

11. A. Almazouzi, M.-P. Macht, V. Naundorf, G. Neumann. Phys. stat. sol. (a). 167, 15 (1998). Crossref

12. V. V. Sagaradze, V.A. Shabashov. Phys. Metals Metallogr. 112, 146 (2011). Crossref

13. D. J. Chakrabarti, D.E. Laughlin. Bull. Alloy Phase Diagrams. 5, 59 (1984). Crossref

14. N. J. Simon, E.S. Drexler, R.P. Reed. NIST monograph 177. Properties of Copper and Copper Alloys at Cryogenic Temperatures. U.S. Government printing office, Washington (1992) $850 \mathrm{p}$.

15. T. Toyoda. J. Phys. Soc. Japan. 39, 76 (1975). Crossref

16. Y. Jin, K. Adachi, T. Takeuchi, H. G. Suzuki. Mater. Lett. 32, 307 (1997). Crossref

17. Q. Liu, X. Zhang, Y. Ge, J. Wang, J.-Z. Cui. Metall and Mat. Trans. A. 37, 3233 (2006). Crossref

18. J. B. Correia, H.A. Davies, C. M. Sellars. Acta mater. 45, 177 (1997). Crossref

19. A. Bell, H. A. Davies. Mater. Sci. Eng. A. 226-228, 1039 (1997). Crossref

20. L. Arnberg, U. Backmark, N. Bäckström, J. Lange. Mater. Sci. Eng. 83, 115 (1986). Crossref

21. D. Arias, J. P. Abriata. J. Phase Equilibria. 11, 452 (1990). Crossref

22. S. V. Dobatkin, D. V. Shangina, N. R. Bochvar, M. Janeček. Mater. Sci. Eng. A. 598, 288 (2014). Crossref

23. D. V. Shangina, J. Gubicza, E. Dodony, N. R. Bochvar, P. B. Straumal, N. Y. Tabachkova, S. V. Dobatkin. J. Mater. Science. 49, 6674 (2014). Crossref

24. M. Azimi, G.H. Akbari. Journal of Alloys and Compounds. 509, 27 (2011). $\underline{\text { Crossref }}$ 